\title{
A jó oktatási gyakorlatok a Rendészeti Vezetéstudományi Tanszéken
}

\section{KOVÁCS Gábor ${ }^{1}$}

\begin{abstract}
A Nemzeti Közszolgálati Egyetem Rendészettudományi Karán a hallgatókfelkészítése összetett módon valósul meg, hiszen a végzettek speciális feladatok ellátására készülnek - a nagy többségük hivatásos tiszt lesz. Az oktatói eredményesség folyamatos biztosítása szempontjából meghatározóvá válik a hatékony oktatási módszerek alkalmazása. Az egyetemen az utóbbi évtized a változások jegyében telt el, de a szakmai célok változatlanok maradtak: a Rendészettudományi Kar fö feladata a tisztjelöltek felkészítése, a kiképzés, a képzés, az oktatás és a nevelés.
\end{abstract}

Kulcsszavak: Nemzeti Közszolgálati Egyetem Rendészettudományi Kar, kompetenciaalapú tanulás, jó gyakorlatok, rendészeti vezetéselmélet, Közös közszolgálati gyakorlat

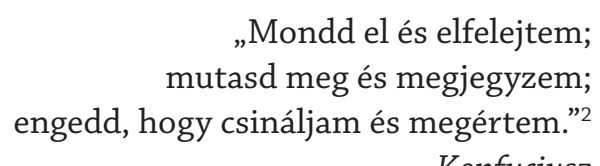

Konfuciusz

\section{Bevezetés}

„A Nemzeti Közszolgálati Egyetem a tudományos kutatás, a tanulás és a tanítás szabadságának intézménye. Az Egyetem az oktatást és a kutatást szolgálatnak tekinti: a magyar közszolgálat fejlesztése útján hozzájárulni az európai integráció közös céljaihoz, valamint a nemzetközi béke, biztonság és szolidaritás ügyéhez."3

A Nemzeti Közszolgálati Egyetem (NKE) Rendészettudományi Kara - cselekvően hozzájárulva az egyetemi stratégiai törekvések megvalósításához, biztosítja a magyar rendészeti szakemberek utánpótlásának jelentős részét.

\footnotetext{
Prof. Dr. KOVÁCS Gábor r. dandártábornok, tanszékvezető egyetemi tanár, Nemzeti Közszolgálati Egyetem Rendészettudományi Kar Rendészeti Vezetéstudományi Tanszék

Prof. Gábor KOVÁCS PhD, Police Brigadier-General, Professor and Head of Department, University Public Service, Faculty of Law Enforcement, Department of Management Science

https://orcid.org/0000-0002-1699-827X; kovacs.gabor@uni-nke.hu

2 Konfuciusz más néven Kung Fu-ce.

3 A biztos jövő egyeteme - Intézményfejlesztési terv 2020-2025. Tervezet 4.0. Nemzeti Közszolgálati Egyetem. é. n. 4.
} 
Hallgatóink felkészítése komplex módon valósul meg, olyan hivatásrendi karrierpályákra készítjük fel őket, amelyek belső tartalma, múködési körülményei napjainkban is gyorsan változnak, pedig a képzési rendszernek előre kell tekinteni legalább 3-4 évvel, hiszen a beiskolázáskor már tudnia kell a kar vezetésének, hogy milyen felkészültséggel, milyen tudással rendelkező tiszteket várnak a képzéseket megrendelő szervezetek. Kivételesen nagy az oktatók felelőssége, hiszen az egyetem falai között a jövő nemzedékek karriertisztjeit ${ }^{4}$ képezzük, évek múlva lesz látható az elvégzett felkészítő munka eredménye, hiszen olyanná formálódik a testület, mint amilyenné a Rendészettudományi Kar képzésein végzett tisztek teszik.

\subsection{A kompetenciaalapú oktatás és az ahhoz kapcsolódó oktatásszervezés}

„Az egyetem legnagyobb értéke a hallgatók és oktatók közösségének együttmúködése" 5 - szerepel az aktuális Intézményfejlesztési tervben, amelynek megvalósítását az oktatók és a hallgatók közötti új típusú kapcsolat - egyfajta partneri viszony - jellemez.

Képzéseink kimeneti követelményei a tudás fejlesztése mellett a képesség, az attitűd, valamint az autonómia és felelősség kompetenciáinak a fejlesztését írják elő. A 222/2019. (IX. 25.) Korm. rendelet ${ }^{6}$ a szakokra vonatkozó követelményeket a nemzettudat, a közszolgálati értékek és a humanitás fogalmaihoz kapcsolódva, azokat kibővítve határozza meg.

A képzési és kimeneti követelményeknek az egyes tantervekbe való beépítése az Egyetem számára egyrészt kötelezettségként jelentkezett, ugyanakkor lehetőséget adott arra vonatkozóan, hogy a Rendészettudományi Kar is megújítsa a teljes képzési portfólióját. Minden, az oktatással foglalkozó egyetemi szervezeti egységnek lehetősége nyílott az alapos előkészítő munka elvégzésére, a tapasztalatok feldolgozására, a hallgatói és oktatói vélemények figyelembevételére, a képzést megrendelő szervezetek szakmai igényeinek érvényre juttatására. Ezen célok érvényesítése érdekében hirdette meg az Egyetem a „Kreatív Tanulás Program”-ot, amelynek értelmében - egyetemi szinten - olyan pedagógiai fordulatot kell kitűzni és érvényre juttatni, amely a korszerú oktatás lényegét, a hallgatói tudás és képességek hatékony fejlesztését irányozza elő, elősegítve és kidolgozva az egyéni tanulási utak mentorálását, a személyes kapcsolatokon alapuló oktatást, nevelést, az alkotó oktatói és hallgatói szakmai közösségek megerősítését.

\footnotetext{
Karriertiszt - ebben az értelmezésben az, aki az érettségit követően kezdte meg tanulmányait a Rendészettudományi Karon - a szerző megjegyzése.

5 A biztos jövő egyeteme - Intézményfejlesztési terv 2020-2025. (é. n.) i. m. 13.

6 222/2019. (IX. 25.) Korm. rendelet az államtudományi képzési területen szerezhető képesítések jegyzékéről és a képzések képzési és kimeneti követelményeiről.
} 
Mindezek a következő célokat foglalják magukban:

- tudásközpontú megközelítés, amelynek célja, hogy a hallgatók valós, a gyakorlati életben is jó használható tudással és ismeretrendszerrel rendelkeznek a képzés befejezésekor;

- kompetenciaközpontú felkészítési rendszer, amely nemcsak a tudásanyag elsajátítását írja elő, hanem az egyes kompetenciák és azon belül a kulcskompetenciák elsajátítását célozza meg;

- egyénileg végrehajtott önálló tanulás helyett a közösségben végzett tanulás, a szükséges elméleti tudás birtokában feladatmegoldások, alkotómunka, amely során az egyének és a csoportok fejlődése az elkészített és leadott munka alapján nyomon követhető;

- az oktató és a hallgató szigorú alá-fölé rendelt viszonya helyett a személyes kapcsolat, a mentorálás, a tanár-diák közötti, egymás munkáját támogató szoros munkakapcsolat, az oktató részéről a közösségi és az egyéni tanulás hatékony támogatása;

- tömegképzés helyett kiscsoportos, hatékony és minőségi felkészítés elősegítése, a tanulási, tanítási feltételek körének biztosítása;

- az egyéni tehetségek kibontakoztatása speciális programok létrehozásával, a szakmai közösségek fejlesztése;

- a hallgatók folyamatos évközi értékelése az elkészített és leadott gyakorlati feladataik és évközi teljesítményük alapján;

- a hallgatók körében az ismeretszerzés igényének és tudásvágynak a felkeltése, az oktatók részéről az élményszerú tanulási módszerek bevezetése és alkalmazása;

- a képzések ismeret- és tudásanyagának, az oktatás módszereinek állandó fejlesztése.

Az alapos elméleti tudás átadása mellett kiemelt célunk a gyakorlatias felkészítés és módszerek alkalmazása (Dale, 1946.), ${ }^{7}$ a képesség, az attitűd- és szemléletformálás, az autonómia és felelősség kibontakoztatása a hallgatók körében. Mindezek mellett a pedagógiai munkának még inkább hallgató központúvá kell válnia, ehhez pedig a jelenleginél érzékenyebb pedagógiai módszerek szükségesek, amelyek a hallgatót középpontba helyező, tanulási, tanítási, gyakorlási és értékelési folyamattal valósíthatók meg. A hallgató központú tanulás-tanítás követelményrendszert minden oktatónak napi szinten alkalmaznia kell, amelynek alapjául a felsőoktatási minőségbiztosítás európai sztenderdje (Standards and Guidelines in the European Higher Education Area: ESG) ${ }^{8}$ szolgál.

\footnotetext{
A Dale által 1946-ban kidolgozott „tapasztalati piramist” továbbfejlesztette Hyland, Bruce 1969-ben, „Értelmezésében egy átlagos ember a szóban vagy írásban kapott információknak mindössze 5-10 százalékát jegyzi meg. A média (például egy film) 25 százalékos teljesítményre képes. A szerepjáték útján történő tanulás 40-60 százalékra emeli a befogadás mértékét. A legjobb, 80-90 százalékos teljesítményt pedig a téma saját bőrünkön való tapasztalata nyújtja”. Forrás: A Dale féle tapasztalati piramis. Hunline.

8 Az Európai Felsőoktatási Térség minőségbiztositásának standardjai és irányelvei (ESG 2015).
} 


\section{A Rendészeti Vezetéstudományi Tanszék által oktatott Vezetés- és szervezéselmélet címú tantárgy oktatásának jó gyakorlata}

\subsection{Az általános kompetenciák, amelyek a vezetéselmélethez kapcsolódó tantárgyak vonatkozásában alakulnak ki}

Ebben a tekintetben irányadó lehet az államtudományi képzési területen a 222/2019. (IX. 25.) Korm. rendelet, az államtudományi képzési területre vonatkozó, a 18/2016. (VIII. 5.) EMMI rendelet 1. számú mellékletében szereplő meghatározások, ${ }^{9}$ a végzettségi szinthez kötődő kompetenciák rendszere és tartalma, amelyek a vezetéselmélettel kapcsolatos tantárgyakra vonatkozóan a következők.

A végzett hallgatók tudása: Összességében átfogó képpel rendelkezik a közszolgálat intézményrendszerének felépítéséről, egyes kiemelt szerveinek működéséről, működésük céljáról, vezetés-irányítási rendszerükről; Átfogóan ismeri az adott képzési terület tárgykörének alapvető tényeit, irányait és határait; Ismeri szakterülete fő elméleteinek ismeretszerzési és problémamegoldási módszereit.

A végzett hallgatók képességei: Más szakterületekkel együttműködve képes müködtetni a normál múködési rendtől eltérő, különleges viszonyok között a hivatásrendjére jellemző szervezeteket; Képes az alsó és középszintű vezető-irányító tevékenység végrehajtására.

A végzett hallgatók attitüdjei: Felismeri az általa irányított szervezet feladatait és lehetőségeit, együttműködik másokkal a különböző jellegű szakmai problémák megoldásában, saját és szervezete tevékenységével szemben kritikus, követelménytámasztó, munkatársaival szemben empatikus, de feladat- és eredménycentrikus, törekszik a kitűzött célok maradéktalan elérésére.

A végzett hallgatók autonómiája és felelössége: Saját, mások és az általa irányított szervezet munkáját önállóan, kellő felelősséggel tervezi, szervezi, irányítja, ellenőrzi. A szakterületéhez kapcsolódóan megfelelő áttekintő-, rendszerező-, rendszerszemléletű képességgel rendelkezik.

Mindezen felsorolt általános kompetenciák kialakításban jelentős szerepet kapnak a vezetéselmélettel összefüggő tantárgyak.

\subsection{A Vezetés- és szervezéselmélet tantárgy tantárgyi programjában meghatározott kompetenciák ${ }^{10}$}

A hallgató tudása: Összességében ismeri, érti, áttekintéssel rendelkezik a közszolgálati szervezetek vezetés-irányítási rendszerében, átfogóan ismeri a vezetés és szervezésel-

A 222/2019. (IX. 25.) Korm. rendelet, az államtudományi képzési területen a 18/2016. (VIII. 5.) EMMI rendelet 1. számú melléklete alapján a szerző által átdolgozva.

10 62-2020. (V. 21.) sz. határozat. A Rendészettudományi Kar egyes szakjai tantervének módosítása valamint elfogadása. A Vezetés- és szervezéselmélet címủ tantárgy tantárgyi programja. alapján a szerző által átdolgozva. 
mélet legfontosabb összefüggéseit, az ehhez kapcsolódó elméleteket, fogalomrendszert, a problémamegoldás módszereit.

A hallgató képességei: Más szakterületekkel együttműködve képes működtetni a normál múködési rendben múködő, a hivatásrendjére jellemző szervezeteket. Képes az alsó, közép- és felső szintű vezető-irányító tevékenység végrehajtására.

A hallgató attitúdjei: Felismeri az általa irányított szervezet feladatait és lehetőségeit, szervezeten belül és kívül együttműködik másokkal a különböző jellegű szakmai problémák megoldásában.

A hallgató autonómiája és felelőssége: Saját, mások és az általa irányított szervezet munkáját önállóan, kellő felelősséggel tervezi, szervezi, irányítja, ellenőrzi.

\section{A Rendészeti Vezetéstudományi Tanszék által oktatott Vezetés- és szervezéselmélet címú tantárgy oktatásának jó gyakorlata}

A tanszék munkatársai által kimunkált és alkalmazott jó gyakorlatok vagy annak részelemei minden karon, minden képzési szinten, minden képzési területen alkalmazhatók, természetesen differenciáltan, a szakmai sajátosságok figyelembevételével.

\subsection{A Vezetés- és szervezéselmélet címú tantárgy tantárgyi programjának felépitése}

A Vezetés- és szervezéselmélet című tantárgy tantárgyi programja úgy épül fel, hogy két-három évfolyamszintű előadást, egy-egy (20-25 fö/csoport) kisebb hallgatói csoportokra bontott szeminárium követ, amelyet lehetőleg minden esetben ugyanaz az oktató vezet le a kurzus teljes ideje alatt. A félévet vizsga zárja, természetesen a szemináriumi csoportot vezető oktató feladata a hallgatók leadott anyagainak ellenőrzése és a vizsgáztatása! A tantárgyi programok összeállítási folyamatában minden tanszéki oktató részt vett, a tananyag tartalma és tantárgydidaktikai felépítése az oktatók közötti konszenzus eredményét tükrözi. A rendelkezésre álló tankönyvek és a szemelvénygyújtemény tartalma lefedi az oktatott tananyag teljes terjedelmét. Az oktatás során az évfolyam-előadásokon hospitációs céllal jelen vannak a szemináriumot vezető oktatók is, figyelik, mi hangzik el a foglalkozáson, ismereteket szereznek azzal kapcsolatban, mit és hogyan dolgozzanak fel a szemináriumokon.

A Rendészeti Vezetéstudományi Tanszék vonatkozásában az előadások anyagai a tanszéki kollektíva által készített „Power Point” és „Prezi” diasorokban is elkészültek, kiegészítve a meglévő tankönyveket és szemelvénygyưjteményt, amelyek digitális és nyomtatott formában is a hallgatók rendelkezésre állnak. A tanszék az egyes vezetéstechnikai helyzeteket bemutató rövid videófilmekkel is rendelkezik, amelyeket a témához kapcsolódóan az előadásokon levetítenek. A tanszék oktatóinak közreműködésével elkészült egy vezetői jó gyakorlatokat bemutató esettanulmány-gyưjtemény, amely 40 különböző 
gyakorlati vezetéselméleti problémát mutat be, illetve dolgoz fel. A hallgatók a példatárban a megadott válaszok alapján kiválaszthatják az optimálisnak tartott megoldást, megoldásokat.

\subsection{A szemináriumok elökészítése és levezetése}

Az oktatás rendszerében a szemináriumok rendkívül fontos szerepet töltenek be, hiszen az a tananyag rendszerezését, a téma iránti további érdeklődés felkeltését és a számonkérés megvalósítását szolgálja.

A hallgatók az első előadáson megkapják a tantárgyi programot, így nyomon tudják követni az egyes foglalkozások témáit. Tanszékvezetői elvárás az, hogy az adott foglalkozáson a betervezett témakör legyen az előadás anyaga. A szemináriumi foglalkozást megelőző évfolyamszintű előadáson a foglalkozás előadója feladatokat határoz meg a hallgatóknak a kiscsoportokban levezetett szeminárium lebonyolításával kapcsolatosan. A tárgyalt témakörhöz kapcsolódó anyagokat feltöltik a Moodle rendszerbe, ahol minden hallgató, minden szükséges háttéranyagot megtalál (tantárgyi program, tankönyv, prezentáció, szemináriumi felkészülési kérdések, ajánlott irodalom, kapcsolódó esettanulmányok stb.). Ezzel a „technikai” módszerrel segítjük a hallgatók felkészülését, hiszen minden segédanyag egy helyen a rendelkezésükre áll. Ezen a tanórán megtörténik a hallgatók felkérése a kiselőadások megtartására és a feladatmeghatározás a gyakorlati feladatok (esettanulmányok) megoldására (mely sorszámú esettanulmányokat dolgozzák fel). Minden hallgató vezetői szerepkörben készül fel az esettanulmányok megoldására, amelyről a szeminárium során ad majd számot.

Az elméleti előadásokat záró utolsó foglalkozást megelőzően megtörténik a szemináriumi kérdések összeállítása (átlagosan 25-30 kérdés), majd átadása a hallgatóknak (irodalomjegyzékkel, oldalszámra meghatározva a tananyag pontos terjedelmét), hogy legyen elegendő idejük a szemináriumi felkészülésre.

\subsection{A szemináriumi foglalkozás levezetésének jó gyakorlata}

A foglalkozás első része a jelenléti ív körbeadásával veszi kezdetét, hiszen a tanszék oktatói közössége fontosak tartja azt, hogy a hallgatók fizikailag is legyenek jelen a szemináriumi foglalkozásokon. A Covid-19-járvány miatt átalakított oktatási módszerek (például videókonferencia, webinárium, Moodle távoktatási rendszer alkalmazása) is hasznosnak bizonyultak, a tanszéki oktatók tapasztalatai ezzel kapcsolatosan egyértelműen kedvezőek. (Érdemes megvizsgálni a levelező munkarendes képzések esetében a videókonferencián keresztül megvalósuló oktatás lehetőségének jövőben történő részleges vagy általános bevezetését.)

Az interaktív szemináriumi foglalkozásokon fontos a személyes hallgatói részvétel, hiszen itt történik meg a tanult ismeretanyag rendszerezése és számonkérése, az eset- 
legesen meg nem értett részek, kérdések áttekintése, tisztázása. Leginkább alkalmazott munkamódszer a tananyag rendszerezése során az úgynevezett frontális munka (megjegyzendő, hogy jó előadás esetén általában kevés ilyen tisztázó jellegű kérdés merül fel a hallgatók körében).

A foglalkozás további részében a foglalkozás vezetője - az előzetesen a hallgatók rendelkezésre bocsátott szemináriumi kérdésekből történő véletlenszerủ kiválasztással - kérdéseket fogalmaz meg, amelyekre a hallgatók önként jelentkezéssel vagy kijelölés alapján válaszolnak. Az oktató minden választ értékel (részosztályzatot ad, vagy valamilyen pontozásos rendszer alkalmazásával méri a válaszadók teljesítményét), foglalkozásról-foglalkozásra vezetett nyilvántartásában naplózza a szemináriumokon nyújtott teljesítményt (ezeket a szerepléseket összesítik a kurzus végén, a zárási jegy [vizsgaosztályzat] megítélése során játszanak fontos szerepet).

A foglalkozáson 5-10 szemináriumi kérdés áttekintése után következnek az egyenként öt-nyolc perces kiselőadások (általában $2 \mathrm{db}$ ), amelyeket prezentációs szemléltetéssel támogatnak. Ezeket az előadásokat a hallgatók és a foglalkozás vezetője közösen értékelik, felhívva a figyelmet a fontosabb összefüggésekre és az egyes bemutatott elméleti kérdéseknek a gyakorlatban történő megjelenésére. Ezt a részt a szünet követi, amely alatt a hallgatók kicsit kikapcsolódhatnak, megszakítva ezzel a szeminárium viszonylagos feszességét.

A második tanóra az esettanulmányok megoldásával veszi kezdetét. A részt vevő hallgatók néhány percben - az esettanulmányok gyújteményéből, a témakörhöz kapcsolódó két-három esetet dolgoznak fel, három-öt fős kiscsoportokban (előzőleg az önképzés során már kialakították a megoldással kapcsolatos egyéni álláspontjukat). Az egyes csoportok tagjai konszenzussal kialakítják a válaszukat, és azt röviden ismertetik, majd a csoportok összevetik egymás megoldásait és a foglalkozásvezető segítségével kialakítják a szemináriumi csoport által is elfogadott választ (válaszokat).

Ezt a mozzanatot követi a számonkérés, a zárthelyi dolgozat megírása. A szemináriumot vezető oktató az előzetesen kiadott szemináriumi felkészülési kérdésekből tesztlapot készít több változatban, vagy esszé jellegü kérdéseket választ ki, „A”, „B” esetleg "C” csoportosításban. A hallgatók válaszukat írásban adják meg, általában az öt kérdés megválaszolására rendelkezésre álló idő összesen 20-25 perc. Az esszé jellegű kifejtős kérdések esetében a kivetítőn jelennek meg az egyes csoportok kérdései, így mindenki egyidőben és ezzel az egyszerű módszerrel kivetítve láthatja a saját kérdéseit. A számonkérés során a meg nem engedett segédeszköz használata tilos, azt az oktató szigorúan ellenőrzi.

A dolgozatok összegyüjtése után megtörténik a leadó nevének ellenőrzése, amenynyiben van még elegendő idő, akkor ismét folytatódik a frontális munka, amelynek módszere a zárthelyi kérdések válaszainak rövid áttekintése, önként jelentkezés vagy kijelölés alapján (a kérdésekre kapott válaszokat, a foglalkozás vezetője szintén értékeli). Ezt a mozzanatot a foglalkozás összegzett értékelése követi, megtörténik az egyes hallgatói szerepléseknek az értékelése, az érdeklődés felkeltése a további ismeretgyűjtésre, majd utalás történik a következő szemináriumi foglalkozás levezetésére vonatkozóan. 
A tanóratervezési lehetőségek sajnos nem minden esetben teszik lehetővé a kisebb létszámú szemináriumi csoportok létrehozását. Egyes esetekben százas nagyságrendben vannak jelen a hallgatók a szemináriumokon és a számonkéréseken. Ebben az esetben az egyik megoldás a tesztlap készítése és kitölttetése. A tesztlapokon több típusú kérdés szerepelhet, feleletválasztásos, feleletkiegészítéses, igaz-hamis, sorbarendezős, esszé kifejtése stb., ennek az előkészítése, sokszorosítása, a különböző változatok kialakítása idő- és eszközigényes oktatói feladat.

Célravezető módszer lehet az, ha a számonkérést az oktató teszt formájában készíti elő, „A” és „B” csoportbontásban, PowerPoint-diasoron. A hallgatók az előadóteremben a lehetőségek függvényében egymástól szétültetve, egy előre elkészített üres teszt-válaszadó táblázatot kapnak, a két csoport kérdéseit és a lehetséges válaszokat egy-egy diakockán vetítik ki, amelyek megjelenítése időzített, azt a válasz megadásához szükséges időmennyiség alapján állítják be (például 15 s, 40 s stb.) - ez az időmennyiség kérdésenként változhat is. A súgások elkerülésére a lehetséges válaszok betújelei mássalhangzókkal vannak megjelenítve, például B (bé), D (dé), P (pé), V (vé) stb. A hallgatók az adott kérdéshez tartozó helyes válasz betűjelét jelölik be a „totó jellegú” válaszadói íven, amelynek javítása a javítósablon alkalmazásával történik meg, amely módszer rendkívül hatékony az oktatói időfelhasználás szempontjából.

Sikeresen alkalmazható még a Moodle rendszer tesztprogramjának az alkalmazása, amelynek egyedüli hátránya az, hogy a kitöltést végző hallgató a válaszadás során segédeszközöket vehet igénybe abban az esetben, ha nem ellenőrzött körülmények között történik meg a teszt kitöltése (például oktató által felügyelt számítógépes kabinet). A Moodle programban a különböző típusú kérdések nagy változatossággal előkészíthetők, a kérdésbank létrehozása után, a véletlenszerű kérdéskiválasztás beállításával, mindenki más kérdéssorra adja meg a válaszát. Természetesen a kérdés megválaszolására rendelkezésre álló idő is kérdésenként beszabályozható. Nagy előnye az alkalmazás használatának, hogy a megadott hallgatói válaszok alapján a kiértékelést az előre beállított követelményeknek és elvárásoknak megfelelően a program önállóan végrehajtja. Az oktató mentesül a dolgozatok kijavításával járó leterheltség alól, a hallgató is azonnal értesül az eredményről, arra nem kell napokat várni.

\subsection{Az interaktív típusú szemináriumi foglalkozások föbb tapasztalatai, következtetések}

A szemináriumi csoport viszonylagosan kis létszáma és az együtt töltött alkalmak miatt a foglalkozás vezetője személyesen megismeri a csoport tagjait, egyfajta bizalmi viszony alakul ki az oktató és a hallgatók között, ezáltal könnyebben megvalósul a személyes interakció.

A Moodle rendszerben az egyes foglalkozásokhoz minden segédanyagot biztosítunk, jó gyakorlat lehet még a tananyag megküldése a tanulócsoport közös e-mail-címére is. Minden oktató részéről elvárt a tanulás segítése, fontos követelmény az, hogy pontosan 
meg kell határoznia a felkészülési anyagok feltalálási helyét, ezzel együtt is minden segítséget meg kell adni a hallgatónak a hatékony felkészülésre.

A gyakorlatorientált felkészítés szellemében követendő jó gyakorlat lehet az is, hogy az esettanulmányok vonatkozásban minden hallgató a szemeszter zárásának időpontjáig digitális úton adja meg válaszait az adott gyakorlati problémákra.

A szemináriumok kiscsoportos jellege biztosítja az oktatók és a hallgatók személyes kapcsolatát, a számonkérés során nem lehetséges a passzív részvétel, a hallgatók megértik, hogy a folyamatos év közbeni tanulás eredménye a jó-jeles szintű zárthelyi eredmény, amely kiegészül még az egyéb szereplésekre kapott osztályzattal is. Az előző évek tapasztalata az, hogy a hallgatók nagy többsége felismeri e kedvező lehetőségeket - a folyamatos tanulás előnyeit -, és igyekszik jól megfelelni a követelményeknek.

Megvalósul a kiselőadások megtartásával a szóbeli szereplés lehetősége, a gyakorlati problémák megoldásával fejlődik a kreativitás, a gondolkodva tanítás, a szakmai nevelés.

A tanulmányban ismertetett módszerrel levezetett szeminárium alapos és időigényes előzetes oktatói és hallgatói felkészülést igényel, de ez az elvárás mindenkinek az érdekét szolgálja (ez az előzetes felkészülés egyaránt kötelessége az oktatónak és az oktatottnak is).

A Rendészeti Vezetéstudományi Tanszék ilyen típusú, interaktív szemináriumokat vezet le a legtöbb olyan hallgató megelégedésére, aki azért vesz részt a képzésen, mert tanulni szeretne, és felismeri azt, hogy alapvégzettséggel is előbb-utóbb vezető válik majd belőle, ahol hasznosítania kell az ezeken a foglalkozásokon megszerzett elméleti és gyakorlati kompetenciákat.

\section{A Rendészeti Vezetéstudományi Tanszék által oktatott Közös közszolgálati gyakorlat címú tantárgy oktatásának jó gyakorlata}

A NKE minden alapképzési szakjának tanterve magában foglalja - a Ludovíceum tantárgycsoportba tartozó - Közös közszolgálati gyakorlat című tantárgyat, amelynek oktatását az egyetemen a Rendészeti Vezetéstudományi Tanszék koordinálja.

Hazánkban az államtudományi képzési terület szereplőinek felkészítése szorosan összekapcsolódik egymással. A szervezetek vezetői az alkotmányos jogrend alapállapotában és az alkotmányos jogrendtől eltérő, rendkívüli jogrend érvényesülésének időszakában is a feladataikat közösen, egymással szoros együttmúködésben teljesítik. Célunk az, hogy az egységes felkészítő munka eredményeként, végzett hallgatóink várhatóan az egységes elvek, módszerek, elmélet és gyakorlat alapján kezeljék majd a fenyegető veszélyek elhárítását.

A tantárgy keretein belül a hallgatók kulcskompetenciái fejlődnek, az elméleti felkészítés során megismerik egymás szervezeteinek munkamódszereit, ez által készülnek fel az együttmúködési feladatokra. A tantárgy utolsó mozzanataként a hallgatók részt vesznek - a minden évben megrendezett - egyetemi közös közszolgálati gyakorlaton (gyakorlat). 
A tantárgy fontossága rendkívüli, hiszen nélküle nagyon nehéz lenne megérteni azt a bonyolult és összetett rendszert, amelyben a közszolgálati szervezetek együttesen tevékenykednek.

\subsection{A Közös közszolgálati gyakorlat oktatásának jó gyakorlata által fejlesztett kompetenciák}

A tantárgyi program pontosan ${ }^{11}$ tartalmazza azon kompetenciáknak a leírását, amelyek a tantárgy teljesítése során kialakulnak. Ezekből itt csak néhányat emelek ki.

A hallgató tudása: Összességében ismeri, érti, áttekintéssel rendelkezik a közszolgálati szervek vezetés-irányítási rendszerében; Birtokában van az általánostól eltérő különleges viszonyok között a szervezetek vezetéséhez szükséges ismereteknek.

Kiemelt gondot fordítunk a hallgatói képességek fejlesztésére: Más szakterületekkel együttmüködve képes múködtetni a normál múködési rendtől eltérő, különleges viszonyok között a hivatásrendjére jellemző szervezeteket; Képes az alsó, közép- és felső szintű vezető-irányító tevékenység végrehajtására; Jártas a törzsmunkában, ahol aktív tervező, szervező, irányító munkavégzésre képes.

Fontos feladat a hallgatói attitüd formálása. A tantárgyi program ebben a tekintetben célul tűzi ki azt, hogy a végzett hallgató: Felismeri az általa irányított szervezet feladatait és lehetőségeit, együttműködik másokkal a különböző jellegű szakmai problémák megoldásában, saját és szervezete tevékenységével szemben kritikus, követelménytámasztó, munkatársaival szemben empatikus, de feladat- és eredménycentrikus, törekszik a kitűzött célok maradéktalan elérésére.

Kiemelt figyelmet fordítunk a hallgatói autonómia és felelősség fejlesztésére: A tantárgy elsajátítását követően célunk, hogy a hallgató saját, mások és az általa irányított szervezet munkáját önállóan, kellő felelősséggel tervezi, szervezi, irányítja, ellenőrzi.

\subsection{A Közös közszolgálati gyakorlat tantárgy oktatásával kapcsolatos jó gyakorlat bemutatása}

A tantárgyi program részletesen tartalmazza a tananyag szerkezetét, amelyben az egyes foglalkozások egymásra épülése szigorú követelmény. A Közös közszolgálati gyakorlat című tantárgy oktatásához, a képzésért felelős Rendészeti Vezetéstudományi Tanszék - valamennyi hivatásrend közremüködésével - elkészítette a Közszolgálati müveletirányítási rendszerek című tankönyvet,12 amely külön-külön hivatásrendi fejezetekben tárgyalja a különleges jogrend során és a különleges helyzetekkel kapcsolatos feladat- és tevékenységrendszert.

\footnotetext{
62-2020. (V. 21.) sz. határozat. A Rendészettudományi Kar egyes szakjai tantervének módosítása, valamint elfogadása. A Közös közszolgálati gyakorlat című tantárgy tantárgyi programja alapján a szerző által átdolgozva.

12 Kovács Gábor (szerk.): Közszolgálati műveletirányítási rendszerek. Budapest, Dialóg Campus, 2017.
} 
A tankönyv hasznosítható példákat, olyan javasolt algoritmusokat tartalmaz, amelyeknek felhasználásával a hallgatók eredményesen felkészülhetnek a gyakorló beosztásaikra, valamint elkészíthetik a különböző elvárt tevékenységek vezetéséhez szükséges munkaanyagokat.

\subsection{Az elöadások levezetése során alkalmazott jó gyakorlat}

Minden szemeszter kezdetén a tanszékvezető, aki egyben a tantárgy felelőse is, oktatói módszertani foglalkozás keretében feldolgozza a tantárgy oktatásával kapcsolatos didaktikai módszereket, követelményeket és elvárásokat. Erre azért van szükség, mert a tantárgy oktatásában több hivatásrend oktatója működik közre, minden oktató a saját szakmájának témáit oktatja, szükséges az azonos követelménytámasztás, az oktatási módszerek és a számonkérések egységesítése.

$\mathrm{Az}$ előadásokon a tantárgy oktatói kiemelt figyelmet szentelnek az interaktív és élményalapú tanulási módszereknek. Célunk az, hogy a hallgatók gondolkodását, szemléletmódját formáljuk, kitágítsuk azt a területet, amely csak az adott hallgató hivatásrendjét fedi le.

Oktatóink minden tanulócsoport számára tanulási élmények közvetítése útján dolgozzák fel a szükséges elsajátítandó ismereteket. Rendelkezésre állnak videófilmek, amelyek bemutatják az egyes hivatásrendi törzsekben folyó tevékenység egyes részleteit, ezáltal a hallgatók nemcsak elméletben tanulhatják meg, hanem a gyakorlatban is láthatják a különböző hivatásrendi törzsekben folyó munkavégzést.

A tantárgy oktatói tudatosan törekszenek arra, hogy a hallgatók az előtanulmányi ismereteik során elsajátított vezetési és szervezési ismereteket is beépítsék, hozzákapcsolják a kapcsolódó tudásanyag-tartalomhoz, ezáltal az új ismeretek már a korábban megszerzett ismeretekkel ötvöződnek, és azok egységes logikai rendszert alkotva, komplex módon megjelennek a hallgatók tudásában.

\section{A Közös közszolgálati gyakorlat tantárgy belső tartalma}

A Közös közszolgálati gyakorlat címú tantárgy elméleti és gyakorlati részeket is tartalmaz. Az elméleti foglalkozások az általános bevezető foglalkozással kezdődnek, majd azt követően bemutatja a katonai szervezetek, a rendészeti szervezetek és a közigazgatási szervezetek törzs munkáját, valamint az egyezményes jelek és az együttműködés alapjai címú témaköröket.

A gyakorlat előkészítése kétszer két tanóra keretében zajlik le, ahol a hallgatók rendelkezésére bocsájtjuk az „Alap és indító feladatot” és a „Kiegészítő és részletes feladatot” (ezekből a feladatokból oktatói és hallgatói példányok is a rendelkezésünkre állnak, a különbség annyi a két feladat között, hogy az oktatói példányok tartalmazzák a lehetséges megoldási változatokat is, ez nagymértékben segíti a foglalkozások vezetőit). 
Ezeken az elméleti jellegű, de a gyakorlatot előkészítő foglalkozásokon megtörténik a kiscsoportok létrehozásával a gyakorlat helyzetbeállítása, a kialakult konfliktusés veszélyhelyzet kezelésében részt vevő nemzetközi és hazai szervezetek szerepének, feladatainak, hatósági jogköreinek, tevékenységüknek az áttekintése, amelyek alapján megtervezhető bevonásuk, illetve részvételük a veszélyhelyzetek elhárításában. Ezekre a foglalkozásokra a hallgatók az előzetes feladatszabás alapján már fel tudnak készülni, így a tanulási folyamatban megtörténik a tananyag célirányos feldolgozása.

A második alkalommal levezetett gyakorló-előkészítő foglalkozáson részt vevő hallgatók már önállóan, előzetesen felkészülve, a feladatban beállított alaphelyzet alapján, a gyakorló beosztásokból adódó aktuális feladataikat átgondolva érkeznek meg a foglalkozásra. Ekkor a foglalkozás vezetője rövid, írásbeli ellenőrzést hajt végre (néhány kérdéses teszt formájában, annak érdekében, hogy meggyőződjön arról, hogy a hallgatók a gyakorló beosztásuk ellátásához szükséges háttérismeretekkel rendelkeznek-e).

Magának a gyakorlatnak a levezetése két napot foglal magában. Az első napon az általánosan, évek óta bevált gyakorlat szerint két mozzanat zajlik le. A nulladik (előkészítő) mozzanatban közigazgatási, közszolgálati szervek az általános feladataikat végzik el, majd ezt követően az első mozzanatban rátérnek a veszélyhelyzet hatásainak kezelése érdekében történő előzetes felkészülésre. A mozzanatot és az első nap végét a veszélyhelyzet kihirdetése zárja.

A második napon a veszélyhelyzet fokozódik, a második és harmadik mozzanatban a tömeges fenyegetettség időszakába lép a gyakorlat, ekkor megtörténik a veszélyhelyzet hatásainak érdemi kezelése, amely elméleti és gyakorlati tevékenységben is megjelenik. Az utolsó, negyedik (befejező) mozzanatban a közszolgálati és más szervek normál időszaki múködési rendjének a visszaállítása történik meg.

Minden eddig levezetett gyakorlat során megvalósult a magas szintú jogszabályelőkészítés és -alkalmazás, illetve a központi közigazgatási, illetve a rendvédelmi szervek részéről a feladataik folyamatos ellátása, a normál és különleges jogrend időszakában. Modellezték a Kormány, a Katasztrófavédelmi Koordinációs Tárcaközi Bizottság és munkaszervei, az érintett minisztériumok, a védelmi bizottságok és operatív törzsek, központok, az érintett együttmúködők tevékenységét is. A gyakorlaton a szervezetek törzsei folyamatosan üléseznek, intézkedéseket hoznak, beavatkozó tevékenységet végeznek, együttmúködést szerveznek, a kialakult helyzet hatékony kezelése érdekében.

A gyakorlatokat követően minden esetben megtörténik a tapasztalatok összegyüjtése, feldolgozása, azok elemzése. A tapasztalatokat folyamatosan beépítették az oktatási anyagokba. Évek óta leszűrhető tapasztalat és a tanulság az, hogy a különböző egyetemi hallgatók, civilek vagy egyenruhások, kiválóan együtt tudnak múködni, és képesek a különböző feladatokat jó szinten végrehajtani.

Az ismeretek elsajátításához szükséges tananyag és az ehhez kapcsolódó hallgatói feladatok immár több változatban is rendelkezésre állnak, az oktatott hallgatók elégedettek a tantárggyal és magával a gyakorlattal, szeretnek együtt, a közös célok megoldásáért dolgozni - ezt a hallgatói felmérések eredményei is bizonyítják. 
A gyakorlat megvalósítása előtt, alatt és azt követően, kérdőíves felmérés keretében mérjük a résztvevők egymáshoz való viszonyát. ${ }^{13}$ Megállapítás, hogy a gyakorlat hatása kedvező a hallgatók együttműködési készségeinek javítására.

\section{Következtetések}

A Rendészettudományi Kar hallgatóinak oktatása során a Rendészeti Vezetéstudományi Tanszék munkatársai felismerték azt, hogy az oktatási folyamatban mennyire fontos az elmélet és a gyakorlat megfelelő arányának az érvényre juttatása, az egyes tantárgyak oktatása során az interaktív oktatási módszerek alkalmazása, az előadások és a szemináriumi foglalkozások, valamint az ezekre épülő gyakorlatok rendszere. Ezeknek a didaktikai lépéseknek a betartásával, az elméleti felkészítést követően megvalósul a számonkérés és a gyakorlás, amely során lehetőség nyílik az alapvető gyakorlati tapasztalatok megszerzésére. Mindezek biztosítják a hallgatók magabiztosságát az egyes szakmai feladatok végrehajtásában, teljessé téve ezzel a hallgatók és az oktatók közös sikerét.

\section{IRODALOMJEGYZÉK}

A biztos jövő egyeteme - Intézményfejlesztési terv 2020-2025. Tervezet 4.0. Nemzeti Közszolgálati Egyetem. Elérhető: www.uni-nke.hu/document/uni-nke-hu/TERVEZET\%204_0\%20Int\%C3\%A9 zm\%C3\%A9nyfejleszt\%C3\%A9si\%20Terv\%202020-2025.pdf (A letöltés dátuma: 2020. 06. 20.)

Az Európai Felsőoktatási Térség minőségbiztositásának standardjai és irányelvei (ESG 2015). Elérhető: https://enqa.eu/indirme/esg/ESG\%20in\%20Hungarian_by\%20OFI-HAC.pdf (A letöltés dátuma: 2020. 06. 16.)

Kovács Gábor - Pesti Tünde - Tőzsér Erzsébet: A hallgatói magatartásformák megjelenése és változásának folyamata a Nemzeti Közszolgálati Egyetem „Vírus 2019” Közös Közszolgálati Gyakorlatán. Magyar Rendészet, 19. (2019), 2-3. 115-142. DOI: https://doi.org/10.32577/mr.2019.2-3.7

Kovács Gábor (szerk.): Közszolgálati müveletirányítási rendszerek. Budapest, Dialóg Campus, 2017.

\section{Jogforrások}

Magyarország Alaptörvénye (2011. április 25.)

222/2019. (IX. 25.) Korm. rendelet, az államtudományi képzési területen a 18/2016. (VIII. 5.) EMMI rendelet 1. számú melléklete. Elérhető: http://njt.hu/cgi_bin/njt_doc.cgi?docid=196922.364718, http://njt.hu/cgi_bin/njt_doc.cgi?docid=215913.372691) (A letöltés dátuma: 2020. 06. 16.)

62-2020. (V. 21.) sz. határozat. A Rendészettudományi Kar egyes szakjai tantervének módosítása, valamint elfogadása. A Vezetés- és szervezéselmélet című tantárgy tantárgyi programja.

13 Kovács Gábor - Pesti Tünde - Tőzsér Erzsébet: A hallgatói magatartásformák megjelenése és változásának folyamata a Nemzeti Közszolgálati Egyetem „Vírus 2019” Közös Közszolgálati Gyakorlatán. Magyar Rendészet, 19. (2019), 2-3. 115-142. 
Elérhető: www.uni-nke.hu/egyetem/szenatus/szenatusi-hatarozatok/2020 (A letöltés dátuma: 2020. 06. 21.)

62-2020. (V. 21.) sz. határozat. A Rendészettudományi Kar egyes szakjai tantervének módosítása valamint elfogadása. A Közös közszolgálati gyakorlat című tantárgy tantárgyi programja. Elérhető: www.uni-nke.hu/egyetem/szenatus/szenatusi-hatarozatok/2020. (A letöltés dátuma: 2020. 06. 21.)

\section{Internetes források}

A Dale féle tapasztalati piramis. Hunline. Elérhető: http://okt.ektf.hu/data/forgos/file/tananyag/forgo/523_a_dale_fle_tapasztalati_piramis.html (A letöltés dátuma: 2020. 06. 23.)

Konfuciusz idézet. Citatum. Elérhető: www.citatum.hu/idezet/11764 (Aletöltés dátuma: 2020. 06. 23.)

\section{ABSTRACT}

\section{Good Educational Practices in the Department of Law Enforcement Management Theory Gábor KOVÁCS}

At the University of Public Service Faculty of Law Enforcement the preparation of students takes place in a complex way, as the graduates are prepared to perform special tasks - the vast majority of them will be professional law enforcement officers. The use of effective teaching methods becomes crucial for ensuring teacher effectiveness. At the university, the last decade has been marked by changes, but the professional goals remain the same: the main tasks of the Faculty of Law Enforcement are to prepare, train and educate the cadets.

Keywords: University of Public Service Faculty of Law Enforcement, competence based education, good practice, law enforcement management studies, Public service exercise 